\title{
Effectiveness of conservative approach in right colon diverticulitis
}

\author{
(ㄷ) Sabahattin Destek, M.D., ${ }^{1}$ 다 Vahit Onur Gül, M.D. ${ }^{2}$
}

${ }^{1}$ Department of General Surgery, Bezmiâlem Vakif University Faculty of Medicine Hospital, İstanbul-Turkey

${ }^{2}$ Department of General Surgery, Gulhane Training and Research Hospital, Ankara-Turkey

\begin{abstract}
BACKGROUND: Approximately 10\%-25\% of patients with colon diverticular disease experience colonic diverticulitis during their lives. Right-sided diverticulosis is a rare condition in Western countries, but it is common among Asian countries. The aim of this study was to evaluate the clinical and treatment outcomes in our patients with right colon diverticulitis.

METHODS: Demographic and clinical data of 22 patients with a diagnosis of cecum and right-sided colon diverticulitis between 2014 and 2017 were analyzed. The Hinchey staging was applied according to the radiological evaluation and clinical findings. Then, the proportions of demographic and clinical features of the patients according to the Hinchey staging and its statistical significance were evaluated.

RESULTS: Our study included 22 patients who suffered from right colon diverticulitis. The female-to-male ratio was 0.69 . A total of $68.1 \%$ of the patients were the Hinchey Stage I, and 31.8\% were the Hinchey Stage II, all of which were evaluated by tomography. The Hinchey Stage I diverticulitis was mostly found in the right colon (66.7\%) and the Hinchey Stage II diverticulitis in the cecum (57.1\%). The mean age of the Hinchey Stage II patients was higher $(63.6$ years) and statistically significant $(p<0.05)$. Two patients had appendectomy, and one had right hemicolectomy. Conservative treatment was applied to other 19 patients. The mean hospitalization time was 3.4 days. Four patients who received conservative treatment at the 2-year follow-up had recurrence. No recurrence was observed in patients receiving surgical treatment.
\end{abstract}

CONCLUSION: Right colon diverticulitis is usually seen in solitary men aged $<50$ years from Eastern societies. As a treatment option, conservative methods should be preferred, especially in uncomplicated cases. Surgical treatment is usually used in the treatment of recurrent and complicated cases.

Keywords: Conservative treatment; Hinchey staging; right colon diverticulitis.

\section{INTRODUCTION}

In the case of colonic diverticula, the colon mucosa is dislodged in the form of an outward pouch. The cases in which more than one diverticulum exists are called diverticulosis coli. ${ }^{[1]}$ Colonic diverticular disease (CDD) was first defined by Cruvelhier in 1849. ${ }^{[1]}$

The prevalence of CDD is $5 \%-45 \%$ in the Western societies. ${ }^{[2]}$ It usually occurs after $\mathbf{5 0}$ years of age and is located in the leftsigmoid colon in $95 \%$ of the cases. ${ }^{[1,2]}$ In approximately $1.5 \%$ of the cases, it is located in the right colon. ${ }^{[1,2]}$ The prevalence of CDD is $0.2 \%$ in Asia and $0.2 \%$ in Africa. ${ }^{[1]}$ It usually occurs before 50 years of age, and in $70 \%$ of the cases, it is found in the right colon. ${ }^{[1-3]}$ Diverticulitis is the most common CDD complication, and it occurs in $15 \%-25 \%$ of the cases. ${ }^{[1,2]}$

Right colon diverticulitis (RCD) is usually solitary and congenital. ${ }^{[4]}$ RCD generally occurs in middle-aged men, and its incidence does not increase with age. ${ }^{[5]}$ It is difficult to distinguish RCD from acute appendicitis because of their similar symptoms and signs.

Cite this article as: Destek S, Gül VO. Effectiveness of conservative approach in right colon diverticulitis. Ulus Travma Acil Cerrahi Derg 2019;25:396-402.

Address for correspondence: Sabahattin Destek, M.D.

Bezmiâlem Vakıf Üniversitesi Tıp Fakültesi, Genel Cerrahi Anabilim Dalı, İstanbul, Turkey

Tel: +90 216 - 4442599 E-mail: sebahattindestek@yahoo.com

Ulus Travma Acil Cerrahi Derg 2019;25(4):396-402 DOI: 10.14744/tjtes.2019.47382 Submitted: 26.10.2018 Accepted: 18.03.2019 Online: 08.07.2019

Copyright 2019 Turkish Association of Trauma and Emergency Surgery 
The aim of the present study was to evaluate the patients with RCD using clinical, laboratory, imaging, and treatment methods in one center. The efficacy of conservative treatment in RCD was evaluated.

\section{MATERIALS AND METHODS}

Patients with RCD among patients with colon diverticulitis followed in the Department of General Surgery between $201 \mathrm{I}$ and 2015 were retrospectively reviewed. In the present study, it was found that 152 patients received treatment for CDD. The patients without RCD, those who had additional pathologies such as colon tumor, those who were pregnant, and those with incomplete data were excluded from the study. Patients diagnosed as having RCD after the operation with a preliminary diagnosis of appendicitis were included in the study.

Twenty-two cases with RCD meeting the inclusion criteria were detected. Age, gender, symptoms, the symptom duration, laboratory results, radiological findings, and treatments of patients were retrospectively analyzed. A body temperature $>38.2^{\circ} \mathrm{C}$ at the time of admission was defined as fever. Blood tests were performed to determine the white blood cell count (upper limit of normal $>10 \times 10^{3} \mu \mathrm{L}$ ) and the level of C-reactive protein (CRP) (upper limit of normal $>0.5 \mathrm{mg} /$ $\mathrm{dL}$ ). All patients underwent abdominal ultrasonography and oral and intravenous tomography. Patients were categorized according to the Hinchey classification by evaluating their radiological imaging features (Fig. I).[2,6]

The conservative and surgical treatment status of the patients was determined. Patients who were not operated and underwent drainage catheterization were evaluated under conservative treatment. By examining the medical records of the discharged patients and taking the information by telephone, we questioned whether the symptoms of diverticulitis recurred after discharge or whether the patient had an operation later.

\section{Statistical Analysis}

Data obtained in this study were evaluated using the SPSS 20.0 package software (IBM, Chicago). The frequency and percentage distributions of the data are presented. Differences between the groups were assessed by normality tests, and the Mann-Whitney $U$ test was used for variables not normally distributed. The chi-squared analysis was used to examine the correlations between the groups of nominal variables. Fisher's exact test was used when the expected values in the tables did not have a sufficient volume, and Pearson's chi-squared analysis was applied using the Monte Carlo simulation in cross-classified $\mathrm{R} \times \mathrm{C}$ tables. A significance level of 0.05 was used, indicating that there was a significant dependence between the groups when $p<0.05$, and no significant dependence between the groups when $p>0.05$.

\section{RESULTS}

Twenty-two patients with RCD were included in the study. Nine (40.9\%) were female, $13(59 \%)$ were male, and the female-to-male $(\mathrm{f} / \mathrm{m})$ ratio was 0.69 . The age range was $26-84$, years, and the mean age of the patients was 50.9 years. The duration of the symptom prior to hospitalization was I-5 days, with a mean of 2.36 days. In general, $59 \%$ of the patients had fever, $54.5 \%$ had nausea, $36.3 \%$ had diarrhea, $54.5 \%$ had pain in the right lower abdomen, and $45.4 \%$ had generalized abdominal pain at the time of admission. Leukocytosis was detected in $77.2 \%$ of all patients. High CRP levels were found in all patients $(100 \%)$.

Abdominal tomography was performed in all patients after oral, rectal, and intravenous contrast administration. Based on the localization, $59 \%$ of the patients had diverticulitis in the right colon, and $41 \%$ of them had diverticulitis in the cecum. The grade and stage of the acute diverticulitis were determined based on the findings of abdominal tomography. Accordingly, $68.1 \%$ of patients with localized pericolonic abscess or phlegmon with a diameter $<5 \mathrm{~cm}$ were classified as the Hinchey Stage I, and $31.8 \%$ of patients with pelvic, intraabdominal, retroperitoneal abscess, $>5 \mathrm{~cm}$ in diameter, but limited, were evaluated as the Hinchey Stage II diverticulitis. The Hinchey Stage I diverticulitis was detected mostly in the right colon (66.7\%), and the Hinchey Stage II diverticulitis $(57.1 \%)$ in the cecum (Fig. 2).

When the age of the patients with RCD was compared according to the Hinchey stages, the mean age of the patients with the Hinchey Stage II was higher (63.57 years), and this was statistically significant $(p<0.05)$. The female-to-male ratio of the patients with RCD was 0.69 , but the gender status
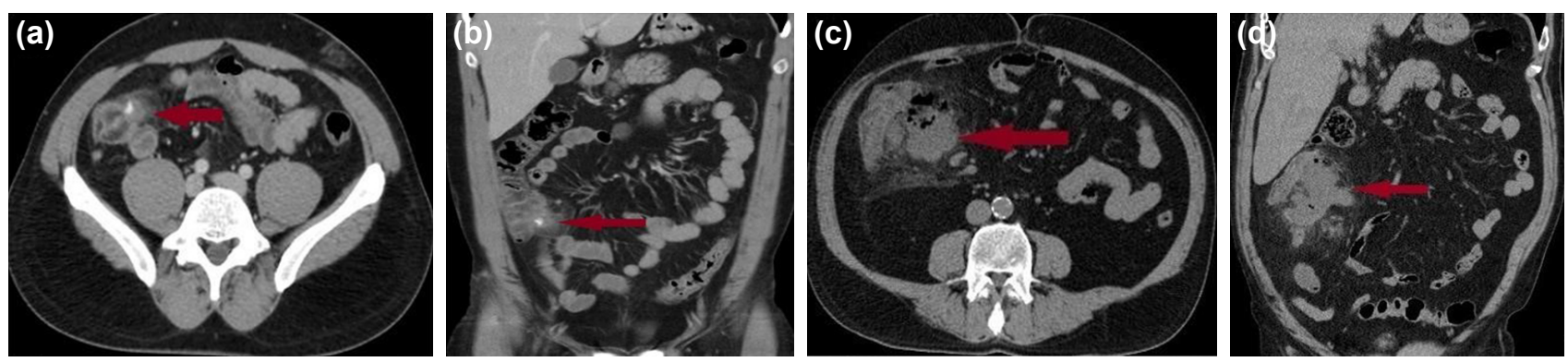

Figure 1. Hinchey Stage I (a and b) - II (c and d) Right colon diverticulitis on tomography. 
Table I. Demographic and clinical characteristics of patients with right colon diverticulitis

\begin{tabular}{|c|c|c|c|c|c|c|c|c|}
\hline \multirow[t]{2}{*}{ Parameters } & \multicolumn{3}{|c|}{ Hinchey Stage I } & \multicolumn{3}{|c|}{ Hinchey Stage II } & \multicolumn{2}{|c|}{ Results } \\
\hline & $\mathbf{n}$ & $\%$ & Mean & $\mathbf{n}$ & $\%$ & Mean & Value & $\mathbf{p}$ \\
\hline Age (years) & 15 & - & 45.7 & 7 & - & 63.57 & 2.507 & $0.012^{*}$ \\
\hline \multicolumn{9}{|l|}{ Gender } \\
\hline Male & 10 & 66.7 & - & 3 & 42.9 & - & 1.068 & $0.376^{*}$ \\
\hline Female & 5 & 33.3 & - & 4 & 57.1 & - & & \\
\hline \multicolumn{9}{|l|}{ Fever $\left(>38.2^{\circ} \mathrm{C}\right)$} \\
\hline Yes & 7 & 46.7 & - & 6 & 85.7 & - & 2.874 & $0.165^{*}$ \\
\hline No & 8 & 53.3 & - & 1 & 14.3 & - & & \\
\hline \multicolumn{9}{|l|}{ Nausea } \\
\hline Yes & 6 & 40 & - & 6 & 85.7 & - & 3.840 & $0.074^{*}$ \\
\hline No & 9 & 60 & - & 1 & 14.3 & - & & \\
\hline \multicolumn{9}{|l|}{ Diarrhea } \\
\hline Yes & 3 & 20 & - & 5 & 71.4 & - & 5.207 & $0.052^{*}$ \\
\hline No & 12 & 80 & - & 2 & 28.6 & - & & \\
\hline \multicolumn{9}{|l|}{ Bottom right } \\
\hline \multicolumn{9}{|l|}{ Abdominal pain } \\
\hline Yes & 11 & 73.3 & - & I & 14.3 & - & 6.407 & $0.020^{*}$ \\
\hline No & 4 & 26.7 & - & 6 & 85.7 & - & & \\
\hline \multicolumn{9}{|l|}{ Generalized pain } \\
\hline Yes & 4 & 26.7 & - & 6 & 85.7 & - & 6.407 & $0.020^{*}$ \\
\hline No & 11 & 73.3 & - & 1 & 14.3 & - & & \\
\hline Pain duration (day) & 15 & - & 1.87 & 7 & - & 3.43 & $2.27 I$ & $0.023^{\#}$ \\
\hline Leucocyte count $(\mu \mathrm{L})$ & 15 & - & 12040 & 7 & - & $|740|$ & 2.152 & $0.03 I^{*}$ \\
\hline CRP (mg/dL) & 15 & - & 4.76 & 7 & - & 14.68 & 2.153 & $0.03 I^{¥}$ \\
\hline
\end{tabular}

*Mann Whitney-U Test. "Fisher's Exact Test. CRP: C-reactive protein.

was not statistically significantly correlated with the Hinchey stages. In general, $59 \%$ of the patients had fever $\left(>38.2^{\circ} \mathrm{C}\right)$, $54.5 \%$ had nausea, and $36.3 \%$ had diarrhea, but these were not statistically significantly correlated with the Hinchey stages. A total of $73.3 \%$ of the right lower abdominal pain in the RCD patients was seen in the Hinchey Stage I patients, and this was statistically significant $(p<0.05)$. On the other hand, $85.7 \%$ of the generalized abdominal pain was seen in the Hinchey Stage Il patients, and this was statistically significant $(p<0.05)$. Duration of pain was higher in the Hinchey Stage II patients (average 3.43 days), and this was statistically significant $(p<0.05)$. Leukocyte and CRP levels were statistically significant in the Hinchey Stage II patients (mean leukocytes, I7,40 I $\mu \mathrm{L}$; CRP $14.68 \mathrm{mg} / \mathrm{dL})(\mathrm{p}<0.05)$ (Table I).

Appendectomy was performed in 2 patients (9\%) as a treatment. Preoperative radiological examinations of these patients were diagnosed as acute appendicitis. One of them was the Hinchey Stage I, and the other was Stage II cecum diverticulitis during the operation. Another patient (4.5\%) had a complex abscess with the Hinchey Stage II cecum di- verticulitis. Right hemicolectomy and primary anastomosis were performed. This patient was discharged with healing after 8 days with no mortality and morbidity in the postoperative period.

Symptomatic conservative treatment was applied in other 19 patients $(86.3 \%)$. Conservative treatment was applied in 14 Hinchey Stage I RCD patients and 5 Hinchey Stage II RCD patients. Oral intake in these patients was discontinued for 2-3 days, intravenous hydration therapy with balanced solutions was given, intravenous dual antibiotherapy was applied, including antibiotics such as third-generation cephalosporins and metronidazole, and after 2-8 days (mean, 3.7 days), they were discharged by oral antibiotics.

A percutaneous drainage catheter was placed under sonography in 4 patients (18.1\%) in who the localized abscess did not regress with conservative treatment. Percutaneous abscess drainage was applied in 2 Hinchey Stage I patients and 2 Hinchey Stage II patients. Patients with a drainage catheter were discharged after 4-5 days of treatment, followed by oral 
Table 2. Treatment and recurrence status of patients with right colon diverticulitis

\begin{tabular}{|c|c|c|c|c|c|c|}
\hline \multirow[t]{2}{*}{ Parameters } & \multicolumn{2}{|c|}{$\begin{array}{l}\text { Hinchey } \\
\text { Stage I }\end{array}$} & \multicolumn{2}{|c|}{$\begin{array}{l}\text { Hinchey } \\
\text { Stage II }\end{array}$} & \multicolumn{2}{|c|}{ Results } \\
\hline & $\mathbf{n}$ & $\%$ & $\mathbf{n}$ & $\%$ & Value & $\mathbf{p}$ \\
\hline \multicolumn{7}{|l|}{ Treatment } \\
\hline Conservative & 14 & 93.3 & 5 & 71.4 & 1.856 & $0.227^{*}$ \\
\hline Surgery & 1 & 6.7 & 2 & 28.6 & & \\
\hline \multicolumn{7}{|l|}{ Percutaneous } \\
\hline \multicolumn{7}{|l|}{ drainage } \\
\hline Yes & 2 & 13.3 & 2 & 28.6 & 0.711 & $0.565^{*}$ \\
\hline No & 13 & 86.7 & 5 & 74.1 & & \\
\hline \multicolumn{7}{|l|}{ Recurrences } \\
\hline Yes & 2 & 13.3 & 2 & 28.6 & 0.711 & $0.565^{*}$ \\
\hline No & 13 & 86.7 & 5 & 74.1 & & \\
\hline
\end{tabular}

antibiotics. After treatment of all patients, appropriate physical activity, probiotics, and high-fiber diet of herbal origin were recommended to all patients, and they were followed up (Table 2).

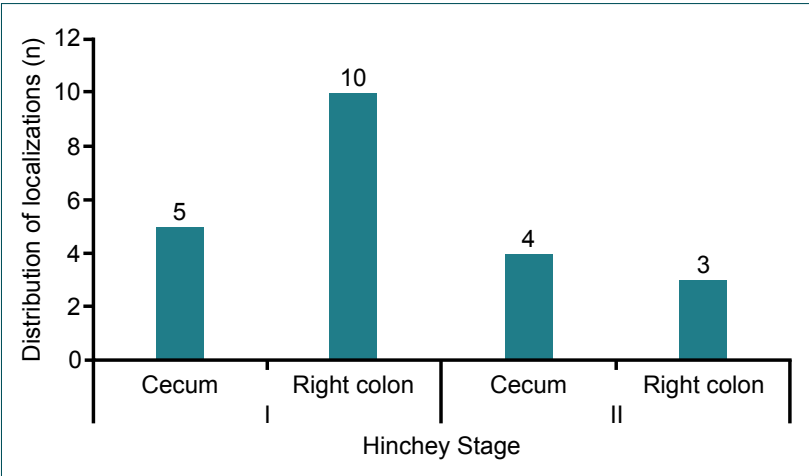

Figure 2. Hinchey Stages of right colon diverticulitis and distribution of localization.

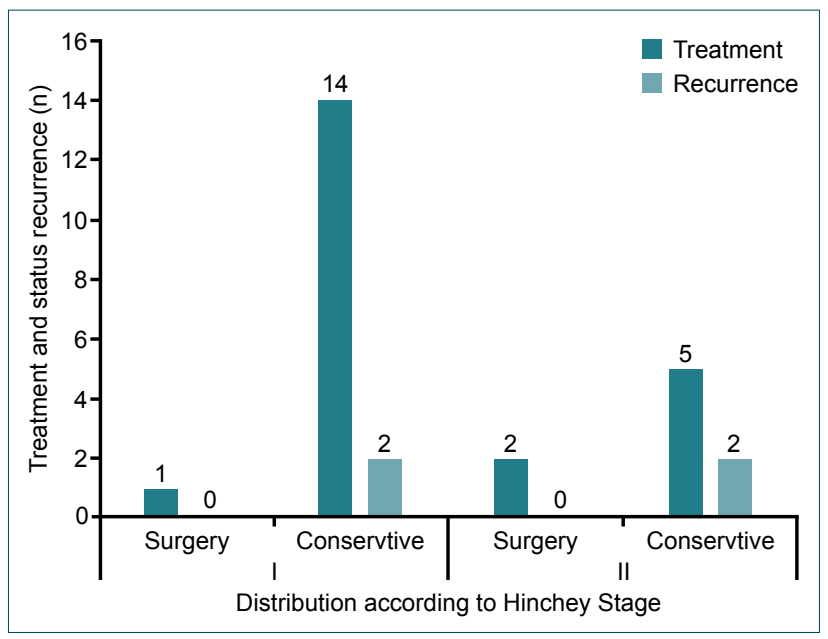

Figure 3. Prognosis status of patients with right colon diverticulitis.
After 2 years of follow-up, no recurrence was detected in patients undergoing surgery. Two Hinchey Stage I patients with conservative treatment and 2 Hinchey Stage II patients developed recurrence. The recurrence status according to the Hinchey stages was not statistically significant. Since recurrence attacks were not complicated, the patients were treated conservatively again, followed by a high-fiber dietary recommendation (Fig. 3).

\section{DISCUSSION}

The pathophysiology of CDD is very complex and is related to colonic motility disorders, chronic inflammation in the colon wall, and microflora imbalance..$^{[1,2,6]}$ In the etiology, factors such as genetics, lineage, reduced fiber intake, obesity, lack of physical activity, muscle diseases, etc. were found to be related to $C D D{ }^{[6,7]} \mathrm{CCD}$ has two forms. Congenital diverticulum is a true diverticulum containing all layers of the column. Acquired diverticulum is a false diverticulum consisting of only colon mucosa. ${ }^{[1-3]}$ Right colon diverticula are usually solitary and true diverticula; muscle hypertrophy is not observed. ${ }^{[7,8]}$

In Western societies, 95\% of CDD cases are found in the sigmoid and left colon, $1 \%-2 \%$ in the right colon, and 6\%-10\% in the whole colon. ${ }^{[3,6]}$ Approximately, $20 \%$ of the cases of CDD occur in the Eastern societies, $70 \%$ of which are in the right colon, and $10 \%-15 \%$ are in the left colon. ${ }^{[6-8]}$ This difference is thought to be due to environmental factors, life diversity, and genetics. ${ }^{[2,7,8]}$

The most important CDD complication is acute colonic diverticulitis, observed in $10 \%-25 \%$ of the cases. ${ }^{[1,2]}$ The pathogenesis of diverticulitis occurs in the form of pressure increase, inflammation, focal necrosis, and micro and macro perforation in diverticula. ${ }^{[2,6]}$ In $25 \%$ of the cases, complicated diverticulitis may occur, and intra-abdominal abscess, perforation, fistula, or obstruction may develop. The mortality rate may range between $12 \%-36 \% .^{[1,3,6]} 41 \%$ of CCD cases requiring emergency hospitalization are colon diverticulitis, and $20 \%$ of them are operated. ${ }^{[9]}$

Strategies for treatment and follow-up have been developed by staging colon diverticulitis. ${ }^{[10,11]}$ The most commonly used of them is the Hinchey staging, which was developed in 1978 and then modified. ${ }^{[6,11]}$ Currently, new staging methods are continued to be developed. ${ }^{[12]}$ We used the Hinchey staging in the present study.

In our research, patients with right-sided diverticulitis constituted $14.4 \%$ of CDD. This was an expected rate for our country, which is located between the Eastern and Western worlds. In our study, $68.1 \%$ of the patients were evaluated as the Hinchey Stage I, and $31.8 \%$ of them as the Hinchey Stage Il diverticulitis. 
In a study, the mean age of patients with RCD was 4I.9, and $78.4 \%$ of them were male. Patients with RCD usually had localized peritonitis. ${ }^{[13]}$ The morbidity rate was $14.2 \%$, and the mortality rate was zero. ${ }^{[13]}$ In the present study, the female-to-male ratio of the patients with RCD was 0.69 , and the mean age was 50.9 years. The mean age of the Hinchey Stage II patients was 63.57 years, and this was statistically significant.

Especially the RCD located in the cecum mostly mimics acute appendicitis. ${ }^{[4,5,13]}$ Studies have shown that RCD was found in $2.7 \%$ of the patients who underwent laparotomy with a diagnosis of acute appendicitis. ${ }^{[14]}$ In laparotomies for appendectomy, the main pathology was RCD in I out of 300 appendicitis cases. ${ }^{[15]}$ Research suggests that appendectomy should be performed to accurately follow-up diverticulitis in such a case. ${ }^{[5,11]}$ In the present study, there were 2 patients undergoing appendectomy for acute appendicitis, but they were diagnosed with cecal diverticulitis.

Pain occurring in $93 \%-100 \%$ of the patients with RCD begins directly in the lower-right quadrant and lasts a long time; in advanced cases, pain becomes generalized. ${ }^{[13]}$ To a lesser extent, there are also nausea and vomiting. ${ }^{[15,16]}$ In the present study, right lower abdominal pain was found in $73.3 \%$ of the Hinchey Stage I patients, and this was statistically significant. The generalized abdominal pain was seen in $85.7 \%$ of the Hinchey Stage II patients, and this was statistically significant. Pain duration was longer in the Hinchey Stage II patients (average, 3.43 days), and this was statistically significant.

Leukocytosis is found in $58 \%$ of the patients with RCD. ${ }^{[4,5]}$ Studies have shown that the leukocyte count and fever are not valuable in distinguishing complicated and non-complicated diverticulitis. ${ }^{[17]}$ On the other hand, it has been reported that CRP can be used as an indicator for the presence of complications. In addition, CRP is a useful tool in predicting the clinical severity of acute diverticulitis. ${ }^{[17,18]}$ However, the presence of a low CRP complex does not mean that the disease can be excluded safely. ${ }^{[17,18]}$ In the present study, the leukocyte and CRP levels were higher in the Hinchey Stage II patients and were statistically significant.

A radiologic examination is the primary diagnostic method for colon diverticulitis. ${ }^{[11,17]}$ Radiologically, water-soluble contrast-enema radiography, abdominal sonography, contrast-enhanced tomography, and magnetic resonance imaging (MRI) are used. ${ }^{[5,6]}$ In the studies, sonography had the sensitivity of $77 \%-98 \%$ and specificity of $80 \%-99 \%$; MRI had the sensitivity of $86 \%-94 \%$ and specificity of $88 \%-92 \% .{ }^{[20]}$ Although sonography and MRI detect some complications of acute diverticulitis and occasionally show differential diagnoses, they are not as sensitive as contrast-enhanced tomography for these indications. ${ }^{[4,10,19]}$ Contrast-enhanced tomography has the sensitivity and specificity of $99 \%$ in right-sided diverticulitis. ${ }^{[5,11,19]}$ In the present study, all patients underwent abdominal sonography and contrast-enhanced abdominal CT.

The Hinchey Stage I patients with uncomplicated diverticulitis and isolated paracolic abscesses $<5 \mathrm{~cm}$ in size on a radiological evaluation without clinical peritonitis findings can be treated conservatively with antibiotics and intestinal resting. [5,21-23] If the patient's clinical condition does not improve, the colon resection and primary anastomosis can be planned. ${ }^{[24,25]}$ If RCD is solitary, only diverticulectomy can be performed because it causes less complication. ${ }^{[3,5]}$

The Hinchey Stage II patients have a pericolic, pelvic, and retroperitoneal limited abscess, but if the abscess is $<5 \mathrm{~cm}$, and the patient's general condition is good, they may recover with conservative medical treatment. ${ }^{[9,21]}$ Otherwise, colon resection is performed with primary anastomosis. ${ }^{[9,21]}$ In $14 \%$ of patients with complicated Hinchey Stage II colon diverticulitis, coloileal, colovaginal, and colorectal fistulas may be found, and additional surgical procedures may be required. ${ }^{[11,20]}$ Laparoscopic surgery can be performed safely and effectively in the Hinchey Stage I and II RCD patients. ${ }^{\text {[22,23] }}$

The Hinchey Grade III colon diverticulitis is associated with purulent peritonitis, has a mortality rate of $15 \%-35 \%$, and a morbidity rate of $70 \%-80 \%$. Segmental colectomy with laparotomy is recommended as emergency surgery in these patients. ${ }^{[1,20,26]}$ Modified Hinchey Stage IV colonic diverticulitis has fecal peritonitis, and its mortality rate is 6 times higher than of purulent peritonitis. ${ }^{[9,27]}$ These patients should have an emergent open laparotomy, peritoneal lavage, segmental colectomy, and stoma. ${ }^{[1,26,27]}$

Percutaneous drainage appears to be an optimal first-line treatment of Stage I and II colonic diverticulitis with an abscess diameter $\geq 5 \mathrm{~cm} .^{\left[{ }^{I I}\right]}$ This option results in a lower morbidity and mortality compared to emergency surgery and up to $74 \%$ success rates. ${ }^{[1,24]}$ Percutaneous drainage allows for stabilization of the patient, stage regression, and the performance of definitive surgical procedures under elective conditions. ${ }^{[9,24]}$ Colonoscopy control is recommended to exclude the neoplasm at least 6 weeks after an acute diverticulitis attack. ${ }^{[3, I I]}$

In other studies, 10-year recurrence rates after conservative treatment of non-complicated RCD patients, which make $75 \%$ of RCD cases, is approximately $20 \%-30 \% .{ }^{[22,23]}$ In complicated patients, which account for $25 \%$ of RCD cases, a recurrence rate in the 10-year follow-up after surgical treatment is $2 \%-10 \% .^{[6,9,22]}$

In the present study, $19(86.3 \%)$ patients were treated conservatively, and 4 (18.1\%) patients underwent percutaneous drainage catheterization. Of the 19 patients treated conservatively, only 4 patients (21\%) developed RCD and were treated symptomatically. 


\section{Conclusion}

Conservative treatment methods should be preferred, especially if there is non-complicated RCD. Surgical treatment should generally be used in patients unresponsive to conservative treatment, and in the treatment of complicated and recurrent cases. The authors declare that they have no conflicts of interest. All authors have read and approved the final version of the manuscript.

\section{Conflict of interest: None declared.}

\section{REFERENCES}

1. Young-Fadok TM, Roberts PL, Spencer MP, Wolff BG. Colonic diverticular disease. Curr Probl Surg 2000;37:457-514. [CrossRef]

2. Tursi A, Papa A, Danese S. Review article: the pathophysiology and medical management of diverticulosis and diverticular disease of the colon. Aliment Pharmacol Ther 2015;42:664-84. [CrossRef]

3. Choi CS, Cho EY, Kweon JH, Lim PS, No HJ, Kim KH, et al. The prevalence and clinical features of colonic diverticulosis diagnosed with colonscopy. Korean J Gastrointest Endosc 2007;35:146-51.

4. Radhi JM, Ramsay JA, Boutross-Tadross O. Diverticular disease of the right colon. BMC Res Notes 2011;4:383. [CrossRef]

5. Stollman N, Raskin JB. Diverticular disease of the colon. Lancet 2004;363:631-9. [CrossRef]

6. Hinchey EJ, Schaal PG, Richards GK. Treatment of perforated diverticular disease of the colon. Adv Surg 1978;12:85-109.

7. Commane DM, Arasaradnam RP, Mills S, Mathers JC, Bradburn M. Diet, ageing and genetic factors in the pathogenesis of diverticular disease. World J Gastroenterol 2009;15:2479-88. [CrossRef]

8. Telem DA, Buch KE, Nguyen SQ, Chin EH, Weber KJ, Divino CM. Current recommendations on diagnosis and management of right-sided diverticulitis. Gastroenterol Res Pract 2009;2009:359485. [CrossRef]

9. Schwesinger WH, Page CP, Gaskill HV 3rd, Steward RM, Chopra S, Strodel WE, et al. Operative management of diverticular emergencies: strategies and outcomes. Arch Surg 2000;135:558-62. [CrossRef]

10. Klarenbeek BR, de Korte N, van der Peet DL, Cuesta MA. Review of current classifications for diverticular disease and a translation into clinical practice. Int J Colorectal Dis 2012;27:207-14. [CrossRef]

11. Barat M, Dohan A, Pautrat K, Boudiaf M, Dautry R, Guerrache Y, et al. Acute colonic diverticulitis: an update on clinical classification and management with MDCT correlation. Abdom Radiol (NY) 2016;41:1842-50. [CrossRef]

12. Lee IK, Jung SE, Gorden DL, Lee YS, Jung DY, Oh ST, et al. The diagnostic criteria for right colonic diverticulitis: prospective evaluation of
100 patients. Int J Colorectal Dis 2008;23:1151-7. [CrossRef]

13. Law WL, Lo CY, Chu KW. Emergency surgery for colonic diverticulitis: differences between right-sided and left-sided lesions. Int J Colorectal Dis 2001;16:280-4. [CrossRef]

14. Park CW, Kim BG, Kim KS, Byun YH, Cho KH, Byun SH, et al. Surgical management of caecal diverticulitis detected during appendectomy. J Korean Soc Coloproctol 2001; 17:15-9.

15. Violi V, Roncoroni L, Boselli AS, Trivelli M, Peracchia A. Diverticulitis of the caecum and ascending colon: an unavoidable diagnostic pitfall? Int Surg 2000;85:39-47.

16. Kalcan S, Başak F, Hasbahçeci M, Kılıç A, Canbak T, Kudaş İ, et al. Intraoperative diagnosis of cecal diverticulitis during surgery for acute appendicitis: Case series. Ulus Cerrahi Derg 2015;32:54-7. [CrossRef]

17. van de Wall BJ, Draaisma WA, van der Kaaij RT, Consten EC, Wiezer MJ, Broeders IA. The value of inflammation markers and body temperature in acute diverticulitis. Colorectal Dis 2013;15:621-6. [CrossRef]

18. Kechagias A, Rautio T, Kechagias G, Mäkelä J. The role of C-reactive protein in the prediction of the clinical severity of acute diverticulitis. Am Surg 2014;80:391-5.

19. Kang JY, Melville D, Maxwell JD. Epidemiology and management of diverticular disease of the colon. Drugs Aging 2004;21:211-28. [CrossRef]

20. DeStigter KK, Keating DP. Imaging Update: Acute Colonic Diverticulitis. Clin Colon Rectal Surg 2009;22:147-55. [CrossRef]

21. Yardımcı E, Hasbahçeci M, İdiz UO, Atay M, Akbulut H. Is surgery necessary to confirm diagnosis of right-sided diverticulitis in spite of relevant clinical and radiological findings? Ulus Travma Acil Cerrahi Derg 2017;23:61-5.

22. Komuta K, Yamanaka S, Okada K, Kamohara Y, Ueda T, Makimoto N, et al. Toward therapeutic guidelines for patients with acute right colonic diverticulitis. Am J Surg 2004;187:233-7. [CrossRef]

23. Yang HR, Huang HH, Wang YC, Hsieh CH, Chung PK, Jeng LB, et al. Management of right colon diverticulitis: a 10-year experience. World J Surg 2006;30:1929-34. [CrossRef]

24. Gregersen R, Mortensen LQ, Burcharth J, Pommergaard HC, Rosenberg $\mathrm{J}$, et al. Treatment of patients with acute colonic diverticulitis complicated by abscess formation: A systematic review. Int J Surg 2016;35:201-8.

25. Stabile BE, Puccio E, vanSonnenberg E, Neff CC. Preoperative percutaneous drainage of diverticular abscesses. Am J Surg 1990;159:99-104.

26. Schultz JK, Yaqub S, Wallon C, Blecic L, Forsmo HM, Folkesson J, et al. Laparoscopic Lavage vs Primary Resection for Acute Perforated Diverticulitis: The SCANDIV Randomized Clinical Trial. JAMA 2015;314:1364-75. [CrossRef]

27. Cirocchi R, Trastulli S, Desiderio J, Listorti C, Boselli C, Parisi A, et al. Treatment of Hinchey stage III-IV diverticulitis: a systematic review and meta-analysis. Int J Colorectal Dis 2013;28:447-57. [CrossRef] 


\section{ORİIINAL ÇALIŞMA - ÖZET}

\section{Sağ kolon divertikülitinde konservatif yaklaşımın etkinliği}

\section{Dr. Sabahattin Destek, ${ }^{1}$ Dr. Vahit Onur Gül ${ }^{2}$}

${ }^{1}$ Bezmiâlem Vakıf Universitesi Tıp Fakültesi, Genel Cerrahi Anabilim Dalı, İstanbul ${ }^{2}$ Gülhane Eğitim Araştırma Hastanesi, Genel Cerrahi Kliniği, Ankara

AMAÇ: Kolon divertikül hastalarının yaklaşık \% I0-25'i hayatları boyunca kolon divertiküliti ile karşılaşmaktadırlar. Batı ülkelerinde sağ taraflı divertiküler hastalık nadir görülen bir durum iken, Asya ülkeleri arasında yaygındır. Bu çalışmanın amacı, sağ kolon divertiküliti saptanılan hastalarımızın klinik ve tedavi sonuçlarını değerlendirmektir.

GEREÇ VE YÖNTEM: 20 I I ve 2015 yılları arasında çekum ve sağ kolon divertiküliti tanısıyla tedavi edilen 22 hastanın demografik ve klinik verileri analiz edildi. Radyolojik inceleme ve klinik bulgulara göre hastalara Hinchey Evrelemesi yapıldı. Daha sonra Hinchey Evrelemesine göre hastaların demografik ve klinik özelliklerinin oransal olarak değerlerine ve istatistiksel olarak olarak anlamlılı̆ına bakıldı.

BULGULAR: Araştırmamıza sağ kolon divertiküliti tanısı konulan 22 hasta alındı. Kadın/erkek oranı 0.69 idi. Karın tomografisi ile yapılan değerlendirme sonrasında hastaların \%68. I’i Hinckey evre I, \%3I.8'i Hinckey evre II divertikülit saptandı. Çoğunlukla Hinchey Evre I divertikülit sağ kolonda (\%66.7) ve Hinchey Evre II divertikülit çekumda (\%57.I) bulundu. Hinchey Evre II hastalarının ortalama yaşı daha yüksekti (ortalama, 63.6 yı) ve istatistiksel olarak anlamlıydı $(p<0.05)$. İki hastada apendektomi ve bir hastada sağ hemikolektomi yapılmıştı. Diğer 19 hastaya konservatif tedavi uygulandı. Ortalama hastanede yatış süresi 3.4 gündü. İki yıllık takipte konservatif tedavi alan dört hastada nüks görüldü; cerrahi tedavi alan hastalarda nüks görülmedi.

TARTIŞMA: Sağ kolon divertiküliti genellikle doğu toplumlarında 50 yaş altı erkeklerde ve soliter olarak görülmektedir. Tedavi seçeneği olarak özellikle komplike olmayan olgularda konservatif yöntemler tercih edilmelidir. Cerrahi tedavi ise genellikle nüks ve komplike olguların tedavisinde kullanılmalıdır.

Anahtar sözcükler: Hinchey Evrelemesi; konservatif tedavi; sağ kolon divertiküliti.

Ulus Travma Acil Cerrahi Derg 2019;25(4):396-402 doi: 10.14744/tjtes.2019.47382 